\title{
Estimating Rice Yield under Changing Weather Conditions in Kenya Using CERES Rice Model
}

\author{
W. O. Nyang'au, ${ }^{1}$ B. M. Mati, ${ }^{1}$ K. Kalamwa, ${ }^{1}$ R. K. Wanjogu, ${ }^{2}$ and L. K. Kiplagat ${ }^{3}$ \\ ${ }^{1}$ Jomo Kenyatta University of Agriculture and Technology, P.O. Box 62000, Nairobi 00200, Kenya \\ ${ }^{2}$ Mwea Irrigation and Agricultural Development Centre, P.O. Box 210, Wang'uru 00103, Kenya \\ ${ }^{3}$ Western Kenya Irrigation Schemes, P.O. Box 1010, Kisumu 40100, Kenya \\ Correspondence should be addressed to W. O. Nyang’au; oenganyangau@yahoo.com
}

Received 22 July 2013; Revised 26 December 2013; Accepted 21 January 2014; Published 26 March 2014

Academic Editor: Bernd Lennartz

Copyright (C) 2014 W. O. Nyang'au et al. This is an open access article distributed under the Creative Commons Attribution License, which permits unrestricted use, distribution, and reproduction in any medium, provided the original work is properly cited.

\begin{abstract}
Effects of change in weather conditions on the yields of Basmati 370 and IR 2793-80-1 cultivated under System of Rice Intensification (SRI) in Mwea and Western Kenya irrigation schemes were assessed through sensitivity analysis using the Ceres rice model v 4.5 of the DSSAT modeling system. Genetic coefficients were determined using 2010 experimental data. The model was validated using rice growth and development data during the 2011 cropping season. Two SRI farmers were selected randomly from each irrigation scheme and their farms were used as research fields. Daily maximum and minimum temperatures and precipitation were collected from the weather station in each of the irrigation schemes while daily solar radiation was generated using weatherman in the DSSAT shell. The study revealed that increase in both maximum and minimum temperatures affects Basmati 370 and IR $2793-$ 80-1 grain yield under SRI. Increase in atmospheric $\mathrm{CO}_{2}$ concentration led to an increase in grain yield for both Basmati and IR 2793-80-1 under SRI and increase in solar radiation also had an increasing impact on both Basmati 370 and IR 2793-80-1 grain yield. The results of the study therefore show that weather conditions in Kenya affect rice yield under SRI and should be taken into consideration to improve food security.
\end{abstract}

\section{Introduction}

Agriculture is always vulnerable to unfavorable weather events and climate conditions. Despite technological advances such as improved crop varieties and irrigation systems, weather and climate are important factors, which play a significant role in agricultural productivity [1]. The impacts of climate change on agricultural food production are global concerns and, for that matter, Kenya is not an exception. Climatic factors such as temperature, rainfall, atmospheric carbon dioxide, and solar radiation, among others, are closely linked to agricultural production.

An analysis of the trends in temperature, rainfall, sea levels, and extreme events points to clear evidence of climate change in Kenya. Studies indicate that temperatures have generally risen throughout the country, primarily near the large water bodies $[2,3]$. Other projections also indicate increase in mean annual temperature of 1 to $3.5^{\circ} \mathrm{C}$ by the 2050s [4].
The country's arid and semiarid lands (ASALs) have also witnessed a reduction in extreme cold temperature occurrences [5].

In recent years, Kenya has experienced food shortages arising from declining farm productivity owing to low fertility levels, high input costs, and unreliable weather in the face of a rising population. Being one of stable foods in Kenya, rice productivity is a major concern. Understanding rice production in relation to weather changes is of great importance to boost food productivity.

The system of rice intensification (SRI) offers the opportunity to improve food security through increased rice productivity by changing the management of the plants, soil, water, and nutrients while reducing external inputs like fertilizer and herbicides [6]. The system proposes the use of single, very young seedling with wider spacing, intermittent wetting, and drying and use of mechanical weeders which also aerates the soil and enhances soil organic matter [7]. 
Crop growth simulation models provide the means to qualify the effects of climate, soil, and management on crop growth, productivity, and sustainability of agricultural production [8]. These tools can reduce the need for expensive and time-consuming field trials and could be used to analyze yield gaps in various crops including rice [9]. This study therefore focuses on the assessment of the effects of change in weather conditions (temperature, solar radiation, and atmospheric $\mathrm{CO}_{2}$ concentration) in Kenya on Basmati 370 and IR 2793-80-1 grain yield cultivated under system of rice intensification using the CERES modeling system.

\section{Methodology}

2.1. Description of the Study Area. The study was conducted in four national irrigation schemes in Kenya, namely, Mwea in Kirinyaga county, Ahero in Kisumu county, Bunyala in Busia county, and West Kano in Kisumu county. The four irrigation schemes were chosen to allow for comparative analysis since they occur in different regions of the country of diverse variations and also to make model calibration and validation possible. Mwea irrigation scheme is situated in Kirinyaga county of Kenya. It lies within latitude $37^{\circ} 13^{\prime} \mathrm{E}$ and $37^{\circ} 30^{\prime} \mathrm{E}$ and longitude $0^{\circ} 32^{\prime} \mathrm{S}$ and $0^{\circ} 46^{\prime} \mathrm{S}$. The West Kano irrigation scheme is bounded to the west by Lake Victoria, to the north and south by Nyando and Nyabondo escarpments, respectively, and to the east by the footsteps of Tinderet highlands. It occupies the major part of Kano plains which is located between longitudes $34^{\prime \prime} 48^{\prime}$ and $35^{\prime \prime} 02^{\prime}$ and between latitudes $00^{\prime \prime} 04^{\prime}$ and $00^{\prime \prime} 20^{\prime}$ south [10] and lies to the eastern side of the shores of Winam Gulf of Lake Victoria. It occupies 841 hectares (ha) at an altitude of $1137 \mathrm{~m}$ above sea level.

Bunyala irrigation scheme is located in Busia county of Kenya. It lies in an area with alluvial soils in an altitude of 1135-1200 $\mathrm{m}$ above sea level and it draws its water from Nzoia River and is situated in two locations, namely, Bunyala central which is in Busia district and Usonga in Siaya. Ahero irrigation scheme is located at $0^{\circ} 08^{\prime} 03^{\prime \prime} \mathrm{S}, 34^{\circ} 58^{\prime} 07^{\prime \prime} \mathrm{E}$, $1168 \mathrm{~m}$ above sea level, and in the middle of the Kano plain, $25 \mathrm{~km}$ southeast of Kisumu town. The climate of the Kano plain is relatively dry and the average temperatures are high during the day and the soil of the scheme is of the black cotton type and is rather fertile [11].

\subsection{Material, Methods, and Data Collection}

2.2.1. Plant Material. Basmati 370 and IR 2793-80-1 rice varieties were used in this study. This is because they are the two commonly grown varieties in Kenya.

2.2.2. Field Selection and Design. From each of the four irrigation schemes under study, two SRI farmers were randomly selected and their farms were used as research fields. The rice profile and management practices from nursery till harvest were monitored.

2.2.3. SRI Management Practices Adopted. The crop management data (i.e., agronomic data) required by the model include planting date, planting density, row spacing, planting depth, irrigation amount and frequency, fertilizer application dates, and amounts. The major crop management input data used in the model for simulations in each irrigation scheme are shown in Table 1, which represent typical practices under the system of rice intensification in these irrigation schemes under consideration. The system of rice intensification fundamentals as described by Uphoff [13] comprises (i) early (815-day-old seedling) and quick, shallow (1-2) transplanting, (ii) transplanting single seedling per hill, (iii) wider spacing in a grid pattern, (iv) alternate wetting and drying of the soil, (v) use of push rotary weeder, and (vi) enhancing soil organic matter.

2.2.4. Data Collection. The minimum data sets for the system analysis and crop simulation described in Technical Report of IBSNAT [14] were used as a guide. Data set for this study was obtained from surveys, interviews with the farmers, observations, sample analysis, and use of existing data from meteorological stations and administration offices in Mwea, Bunyala, West Kano, and Ahero irrigation schemes.

The following data was collected as follows:

(i) daily weather data: maximum and minimum air temperature, precipitation, and solar radiation (calculated using weatherman),

(ii) soil data: involved collection of set of input data on soil characteristics at $5 \mathrm{~cm}$ and $25 \mathrm{~cm}$ depths before and during the cropping season (July to December 2011) for Mwea, Ahero, West Kano, and Bunyala irrigation schemes on soil classes, bulk density, organic carbon (\%), sand silt clay (\%), soil texture, $\mathrm{pH}$ of soil in water, organic carbon, cation exchange capacity, total nitrogen, potassium, and phosphorus,

(iii) management practices: variety, plant density, planting date, irrigation, weeding, row spacing, sowing depth, and nitrogen fertilization,

(iv) plant profile data: soil data related to date of sowing, date of emergence, date of floral initiation, date of synthesis, date of physiological maturity, panicle initiation date (when $50 \%$ of the crop had reached those stages) plant population, plant height, grain weight, and grain yield per area of production,

(v) latitude of production area to evaluate day length during the cropping season.

The following six input files were created to run the model:

(i) weather file (FILE.WTH) with annual daily solar radiation, maximum air temperature, minimum air temperature, and precipitation,

(ii) soil file (FILES) with soil properties of the four irrigation schemes under study,

(iii) rice management file (FELEX),

(iv) experimental data file (FILEA) with measured data, 
TABLE 1: Crop management data used in the model.

\begin{tabular}{|c|c|c|c|c|c|}
\hline Serial/number & Simulation parameter & Mwea & Ahero & West Kano & Bunyala \\
\hline 1 & Planting method & Nursery & Nursery & Nursery & Nursery \\
\hline 2 & Cultivar & Basmati 370 & IR 2793-80-1 & IR 2793-80-1 & IR 2793-80-1 \\
\hline 3 & Transplanting date & July 22, 2011 & August 18, 2011 & August 27, 2011 & August 2, 2011 \\
\hline 4 & Planting distribution & Hill & Hill & Hill & Hill \\
\hline 5 & Row spacing & $25 \mathrm{~cm}$ by $25 \mathrm{~cm}$ & $25 \mathrm{~cm}$ by $25 \mathrm{~cm}$ & $25 \mathrm{~cm}$ by $25 \mathrm{~cm}$ & $25 \mathrm{~cm}$ by $25 \mathrm{~cm}$ \\
\hline 6 & Planting depth & $2 \mathrm{~cm}$ & $2 \mathrm{~cm}$ & $2 \mathrm{~cm}$ & $2 \mathrm{~cm}$ \\
\hline 7 & Transplanting age & 8 days & 12 days & 14 days & 10 days \\
\hline 8 & Plant per hill & 1 & 1 & 1 & 1 \\
\hline 9 & Plants per $\mathrm{m}^{2}$ & 16 & 16 & 16 & 16 \\
\hline \multirow{3}{*}{10} & Fertilizer application & & & & \\
\hline & $14 \mathrm{DAP}$ & $125 \mathrm{~kg} \mathrm{ha}^{-1}$ & $125 \mathrm{~kg} \mathrm{ha}^{-1}$ & $125 \mathrm{~kg} \mathrm{ha}^{-1}$ & $125 \mathrm{~kg} \mathrm{ha}^{-1}$ \\
\hline & 34 DAP & $125 \mathrm{~kg} \mathrm{ha}^{-1}$ & $125 \mathrm{~kg} \mathrm{ha}^{-1}$ & $125 \mathrm{~kg} \mathrm{ha}^{-1}$ & $125 \mathrm{~kg} \mathrm{ha}^{-1}$ \\
\hline 11 & $\begin{array}{l}\text { Irrigation application } \\
(\mathrm{mm})\end{array}$ & $\begin{array}{l}410 \mathrm{~mm} \text { in } 16 \\
\text { applications }\end{array}$ & $\begin{array}{l}410 \text { in } 15 \\
\text { applications }\end{array}$ & $\begin{array}{l}360 \mathrm{~mm} \text { in } 13 \\
\text { applications }\end{array}$ & $\begin{array}{l}2200 \mathrm{~mm} \text { in } 14 \\
\text { applications }\end{array}$ \\
\hline
\end{tabular}

(v) genetic coefficients file (FILEC), with thermal time from emergence to the end of juvenile stage (P1), rate of photoinduction (P2R), optimum photoperiod (P2), thermal time for grain filling (P5), conversion efficiency from sunlight to assimilates (G1), tillering rate (TR), and grain size (G2). The cultivar coefficients were determined by Gencalc in the DSSAT version 4.5 using experimental data from Mwea irrigation scheme on Basmati 370 and IR2793-80-1 during the July to December 2010 cropping season.

2.3. Data Analysis. The CERES rice model version 4.5 of the DSSAT modeling system which is an advanced physiologically based rice crop growth simulation model was used to predict rice (Basmati 370 and IR2793-80-1) growth, development, and response to various climatic conditions prevailing in the four irrigation schemes. This was through determination of duration of growth stages, dry matter production and portioning, root system dynamics, effect of soil water and soil nitrogen contents on photosynthesis, carbon balance, and water balance [15] followed by sensitivity analysis to assess the effects of change in weather conditions on Basmati 370 and IR 2793-80-1 grain yield under system of rice intensification.

2.4. Model Calibration. The model was calibrated using Mwea irrigation scheme trials July to December 2010 cropping season SRI experimental data for both Basmati 370 and IR 2793-80-1 for the main cropping season 2010 as reported by Ndiiri et al. [16]. This was through determination of genetic coefficients for both Basmati 370 and IR 279380-1 using Gencalc 4.5 software in the DSSAT 4.5 software and assumed to apply to Ahero, West Kano, and Bunyala irrigation schemes.

2.5. Model Validation. The model was validated using the rice growth and development data under SRI from Mwea,
Bunyala, Ahero, and West Kano irrigation schemes during the cropping season July to December 2011. This was done by comparing the observed results with simulated yield. In this study, combination of graphical, tabular, and statistical analysis was applied. Model performance evaluation was presented by the absolute Root Mean Square Error (RMSE) and Root Mean Square Error normalized (RMSEn). Both characteristics are common tools to test the goodness of fit of simulation models. The RMSE (1) between the simulated and observed values for a data set with $n$ measured points and the RMSEn (2) are defined as

$$
\begin{gathered}
\text { RMSE } \left.=\left[\sum_{i=1}^{n} \frac{(\mathrm{Si}-\mathrm{Ob})^{2}}{n}\right)\right]^{0.5} \\
\mathrm{RMSE}_{n}=100 \frac{\left.\left[\sum_{i=1}^{n}(\mathrm{Si}-\mathrm{Ob})^{2} / n\right)\right]^{0.5}}{\mathrm{Ob}_{\mathrm{avg}}},
\end{gathered}
$$

where $\mathrm{Si}=$ simulated value, $\mathrm{Ob}=$ observed value, and $n=$ number of observations.

The $n$ observed data points may be from one treatment or multiple treatments [17]. Goodness was evaluated visually and by computing index of agreement $(D)$. The index of agreement is defined by [18] as shown in (3). The computed values of RMSE and $d$ value determine the degree of agreement between the predicted values with their respective observed values, and a low RMSE value and a $d$ value that approaches 1 are desirable. Consider

$$
D=1-\frac{\sum_{i=1}^{n}(\mathrm{Si}-\mathrm{Ob})^{2}}{\left.\sum_{i=1}^{n}\left(\mid \mathrm{Si}-\mathrm{Ob}_{\text {avg }}\right)\left|\mathrm{Obi}-\mathrm{Ob}_{\text {avg }}\right|\right)^{2}} .
$$

Normalized RMSE (RMSEn) was used to give a measure (\%) of the relative difference of simulated versus observed data. The simulation was considered excellent with a normalized RMSE less than $10 \%$, good if the normalized RMSE was greater than 10 and less than $20 \%$, fair if the normalized RMSE 


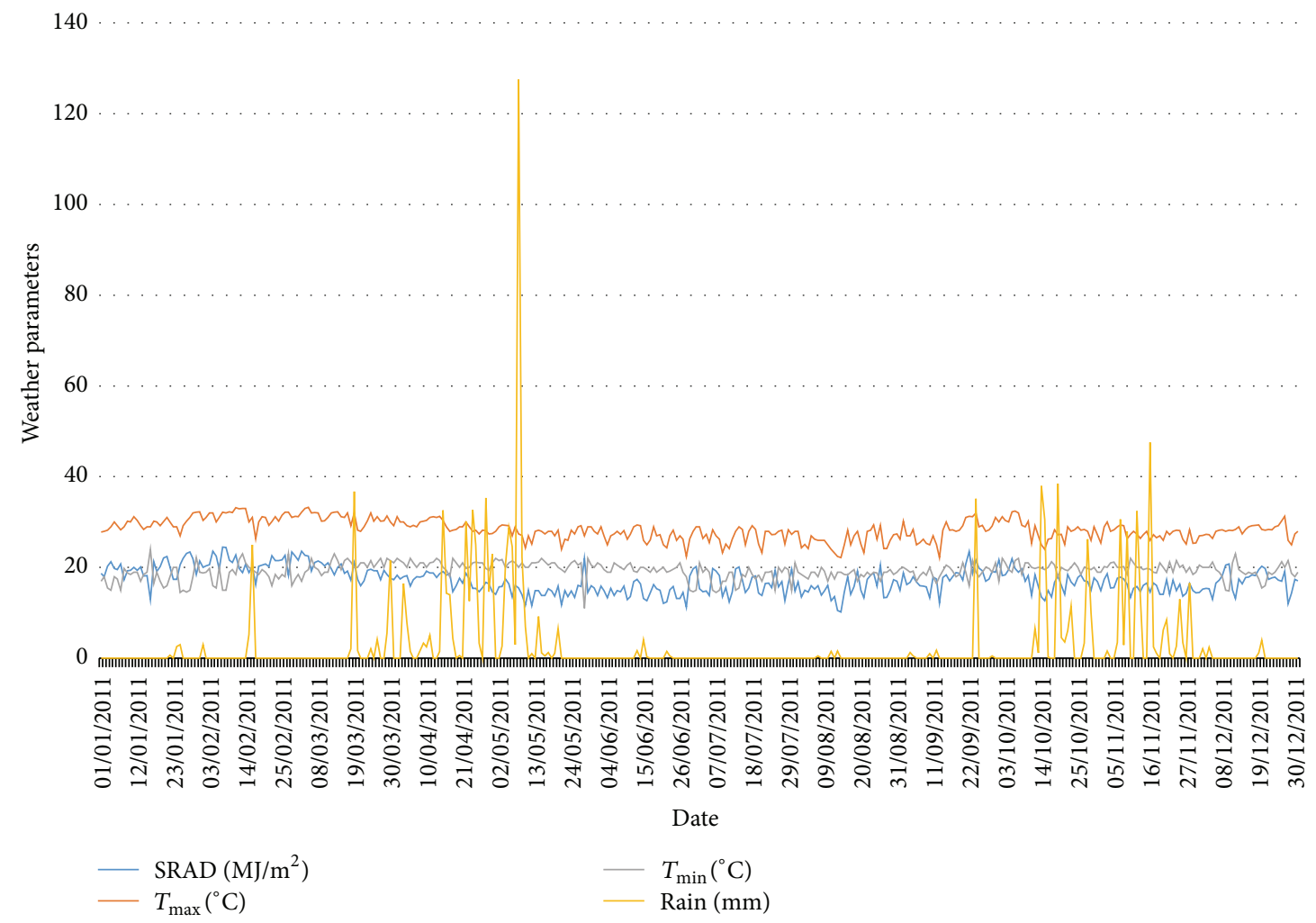

Figure 1: Mwea weather for 2011.

was greater than $20 \%$ and less than $30 \%$, and poor if the normalized RMSE was greater than 30\% [19].

\section{Results and Discussion}

3.1. Weather Conditions during the Cropping Season. According to Hay and Walker, [20] the primary atmospheric variables that impact on crop growth are solar radiation, air temperature, humidity, and precipitation. They mentioned that extreme weather at critical periods of a crop's development can have large effects on its productivity and yield.

3.1.1. Mwea Irrigation Scheme Atmospheric and Hydrological Variables. The climate of Mwea irrigation scheme is tropical governed by seasonal monsoon rainfall patterns which are bimodal. During 2011, maximum and minimum temperatures, rainfall, and solar radiation varied as shown in Figure 1. During the cropping season, the mean maximum temperature $\left(T_{\max }\right)$ and minimum temperature $\left(T_{\min }\right)$ were $27.4^{\circ} \mathrm{C}$ and $19.2^{\circ} \mathrm{C}$, respectively. Mean solar radiation was $16.5 \mathrm{MJ} / \mathrm{m}^{2}$ while total precipitation was $439 \mathrm{~mm}$.

3.1.2. Ahero Irrigation Scheme Atmospheric and Hydrological Variables. Figure 2 shows the atmospheric and hydrological variables for 2011 and part of 2012 in Ahero irrigation scheme. The mean maximum temperature $\left(T_{\max }\right)$ and minimum temperature $\left(T_{\min }\right)$ during the cropping season were $30.1^{\circ} \mathrm{C}$ and $17.0^{\circ} \mathrm{C}$, respectively. Mean solar radiation was $21.1 \mathrm{MJ} / \mathrm{m}^{2}$ while total precipitation was $781.6 \mathrm{~mm}$.

3.1.3. West Kano Irrigation Scheme Atmospheric and Hydrological Variables. During 2011, rainfall, solar radiation, maximum temperature, and minimum temperature varied as shown in Figure 3. Mean maximum temperature $\left(T_{\max }\right)$ and minimum temperature $\left(T_{\min }\right)$ during the cropping season were $27.4^{\circ} \mathrm{C}$ and $17.4^{\circ} \mathrm{C}$, respectively. On the other hand, mean solar radiation was $18.2 \mathrm{MJ} / \mathrm{m}^{2}$ with a total precipitation of $743.4 \mathrm{~mm}$.

3.1.4. Bunyala Irrigation Scheme Atmospheric and Hydrological Variables. Rainfall, solar radiation, maximum temperature $\left(T_{\max }\right)$, and minimum temperature $\left(T_{\min }\right)$ for Bunyala irrigation scheme varied as shown in Figure 4 for 2011 and part of 2012. The mean maximum and minimum growth temperatures were $29.4^{\circ} \mathrm{C}$ and $17.8^{\circ} \mathrm{C}$, respectively, while the mean solar radiation was $19.8 \mathrm{MJ} / \mathrm{m}^{2}$ with a total precipitation of $482.3 \mathrm{~mm}$ during the entire cropping period.

3.2. Genetic Coefficients Determination. The genetic coefficients for both Basmati 370 and IR 2793-80-1 rice cultivars were determined (calibration) by Gencalc software in the decision support system for agrotechnology transfer (DSSAT) using experimental data on real plot research in Mwea irrigation scheme 2010 and the results were assumed to apply to Ahero, Bunyala, and West Kano irrigation schemes. 


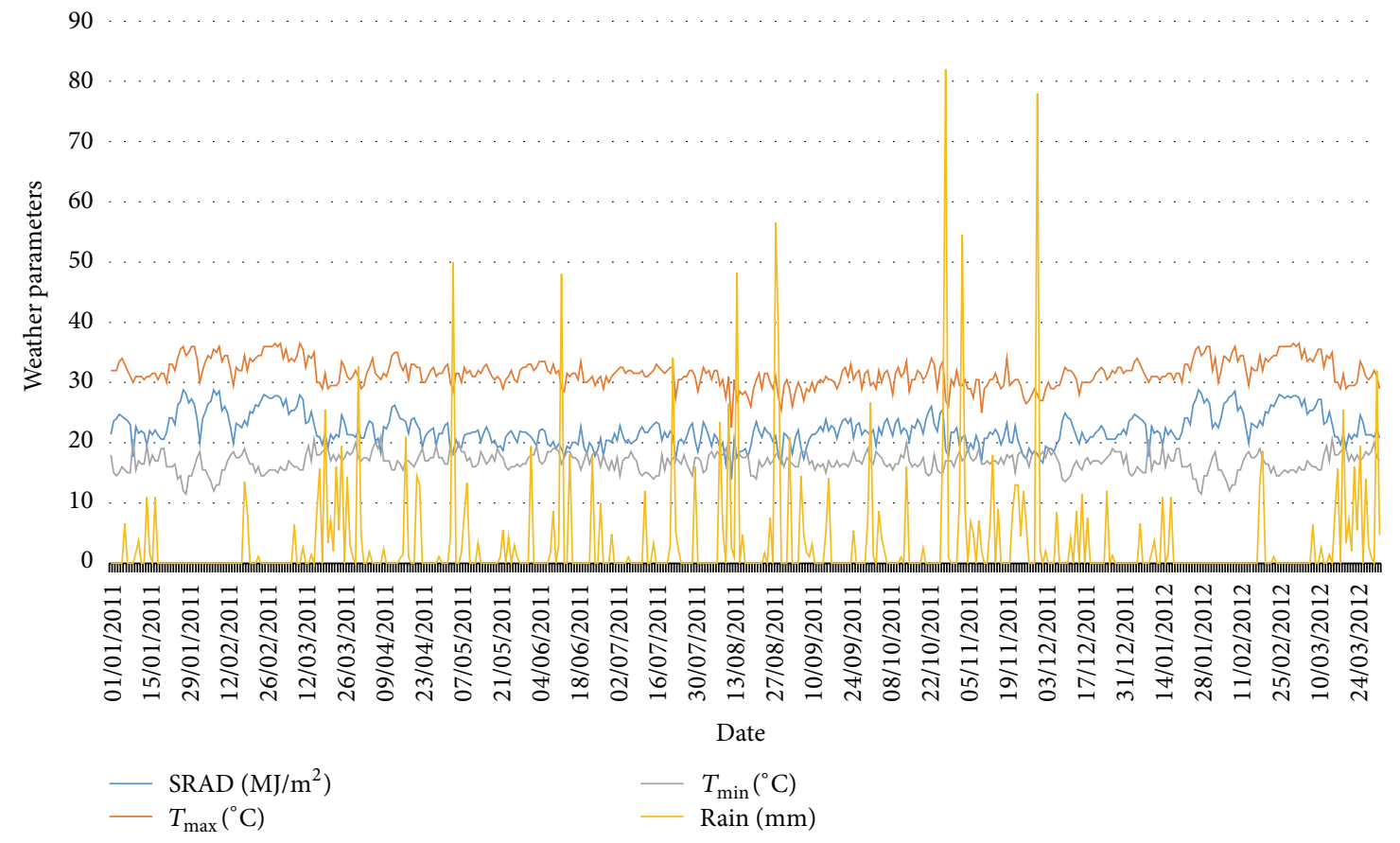

Figure 2: Ahero weather for 2011/2012.

These are the phenological and growth genetic coefficients as described by Peng et al. [21]. Hunt's technique [22] of genetic coefficient calibration was used. This technique estimates genetic coefficients using field data. The processes was finally accomplished by running the model with appropriate coefficients, comparing model output with actual data, adjusting coefficients, and repeating process until acceptable fits were obtained. Table 2 shows the calculated genetic coefficients for Basmati 370 and IR 2793-80-1.

The simulation was considered excellent with a normalized RMSE less than $10 \%$, good if the normalized RMSE was greater than 10 and less than 20\%, fair if the normalized RMSE was greater than $20 \%$ and less than $30 \%$, and poor if the normalized RMSE was greater than 30\% [19]. With a normalized RMSE of $1.528 \%$, the GRAIN YLD target line coefficients were taken as the best coefficients used in this study for Basmati 370. Percentage of RMSE was calculated using the number of data values, not the degrees of freedom. With \%RMSE of 11.45, the GRAIN YIELD target line coefficients were taken as the best coefficients used in current study for IR 2793-80-1.

The final values for the eight cultivar coefficients that determine vegetative ( $\mathrm{P} 1, \mathrm{P} 5, \mathrm{P} 2 \mathrm{O}$, and $\mathrm{P} 2 \mathrm{R})$ and reproductive (G1, G2, G3, and G4) growth and development for Basmati 370 and IR 2793-80-1 are presented in Table 2. The cultivar coefficient P1 defines the time from seedling emergence to the end of juvenile phase (GDD). The coefficient P2O is the extent at which the development occurs at a maximum rate. The coefficient P2R is the extent to which phasic development from vegetative to panicle initiation was delayed for each hour increase in photoperiod above P2O. The coefficient P5 is the time from grain filling to physical maturity. The coefficient
G1 defines the maximum spikelet number coefficient. The cultivar coefficient G2 is the maximum possible single grain size under stress free conditions. The coefficient G3 defines the scalar vegetative growth coefficient for tillering relative to IR64. The cultivar coefficient G4 defines the temperature tolerance scalar coefficient.

Genetic coefficients are sets of parameters that describe the genotype and environmental interactions [14]. They summarize quantitatively how a particular cultivar responds to environmental factors. Estimation involves use of field or growth chamber studies, many samples, and exposure to different photoperiods. Genetic coefficients can be determined in controlled or field conditions. However plant growth in controlled environment chambers often differs markedly from growth in the field. Since most model users do not have controlled environmental facilities, most determinations will use field data $[23,24]$.

3.3. Main Growth and Development Variables for Basmati 370 and IR 2793-80-1 Rice. Tables 3 and 4 show the mean simulated and observed main growth and development variables for Basmati 370 and IR 2793-80-1 under system of rice intensification in Mwea and Western Kenya irrigation schemes, respectively.

3.4. Model Validation. The model was validated using observed growth and phenological data collected during the 2011 cropping season for SRI in Mwea and Western Kenya irrigation schemes. A good match was obtained between observed and simulated grain yield with a RMSE of $0.838 \mathrm{t} / \mathrm{ha}$ and a normalized RMSE (RMSEn) of $15.027 \%$. An index of agreement $(d)$ for grain yield closer to $1(0.875)$ also revealed 


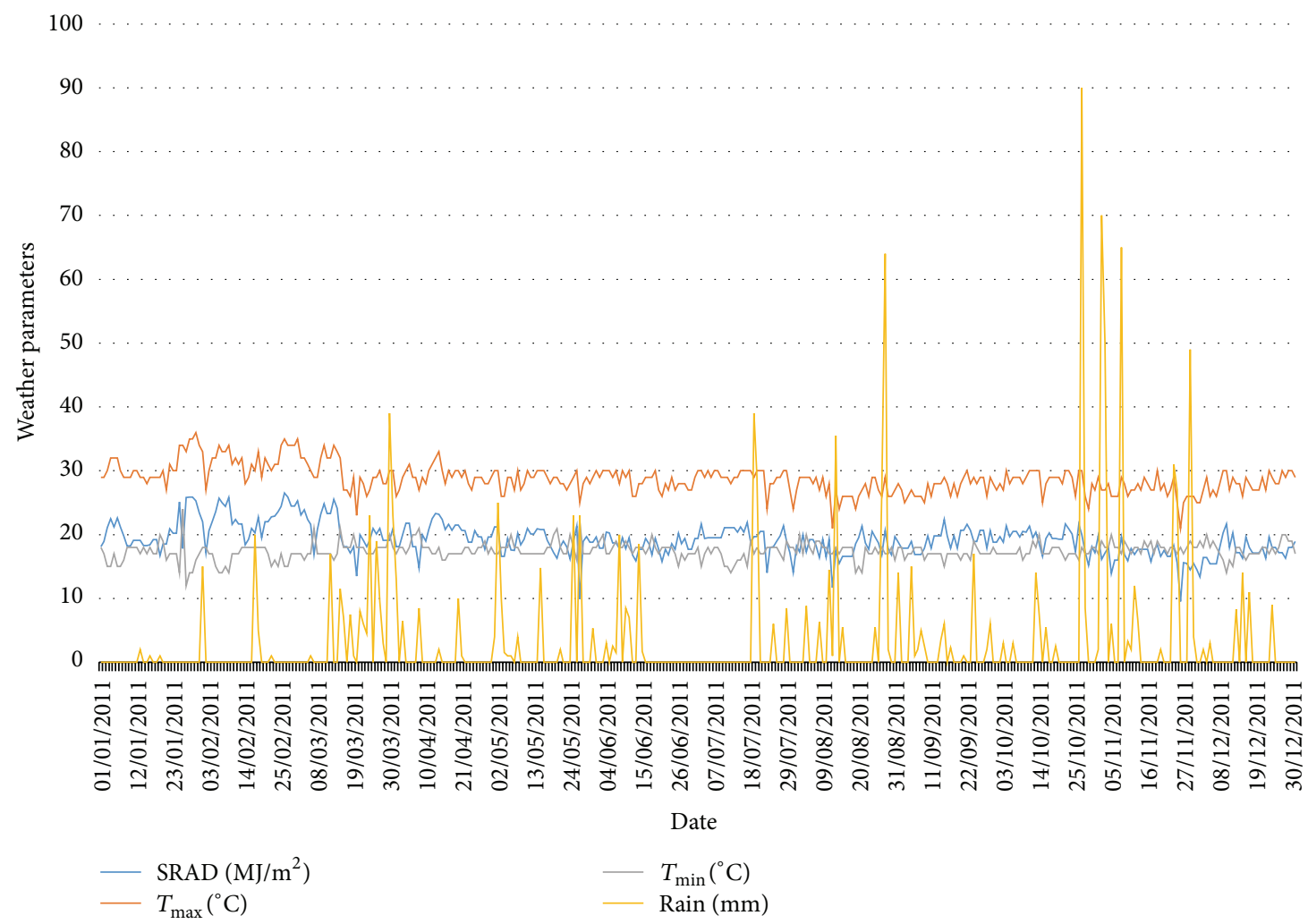

Figure 3: West Kano Weather for 2011.

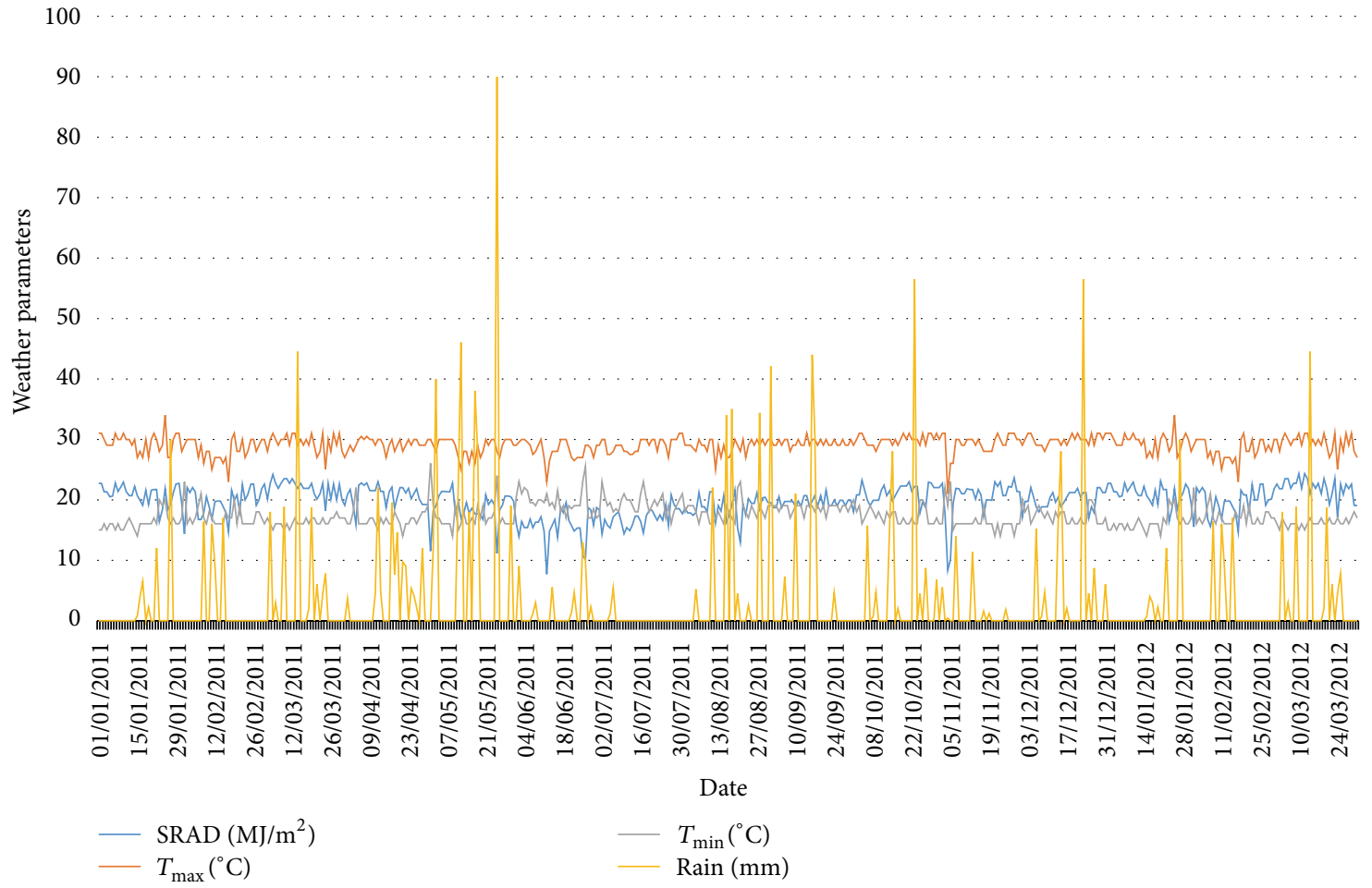

FIGURE 4: Bunyala weather for 2011/2012. 
TABLE 2: Calculated genetic coefficients for Basmati 370 and IR 2793-80-1.

\begin{tabular}{|c|c|c|c|c|c|c|c|c|}
\hline \multirow{2}{*}{ Cultivar } & \multicolumn{8}{|c|}{ Genetic coefficient } \\
\hline & $\mathrm{P} 1$ & $\mathrm{P} 2 \mathrm{R}$ & P5 & $\mathrm{P} 2 \mathrm{O}$ & G1 & G2 & G3 & G4 \\
\hline Basmati 370 & 577.0 & 209.5 & 187.5 & 12.75 & 41.85 & 0.024 & 1.00 & 1.00 \\
\hline IR 2793-80-1 & 540.4 & 150.9 & 240.4 & 12.75 & 63.81 & 0.026 & 1.00 & 1.00 \\
\hline
\end{tabular}

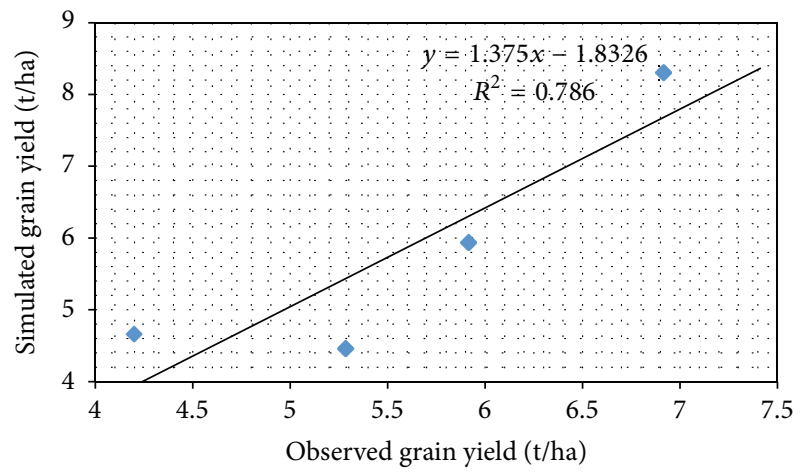

FIGURE 5: Comparison of measured and simulated grain yield of rice under SRI 2011.

TABLE 3: Main growth and development variables for Basmati 370 under system of rice intensification in Mwea irrigation scheme, Kenya.

\begin{tabular}{lcc}
\hline Variable & Simulated & Observed \\
\hline Anthesis & 119 & 110 \\
Physiological maturity (dap) & 139 & 137 \\
Yield at harvest maturity (t/ha) & 5.935 & 5.915 \\
Unit weight at maturity (g) & 0.024 & 0.023 \\
\hline
\end{tabular}

that the model performed well in predicting the yield. The regression analysis gave a coefficient of determination $\left(R^{2}\right)$ value of 0.786 (Figure 5). In general, the results from the model validation indicate that CERES rice version 4.5 was able to predict growth and development for Basmati 370 and IR 2793-80-1 under SRI in Mwea and Western Kenya irrigation scheme in a good manner and therefore can be applied as a study tool.

The $d$-stat of a "good" model should approach unity and the RMSE approach zero. The RMSE is considered as the "best" overall measure of model performance as it summarizes the mean difference in the units of observed and predicted values $[25,26]$.

\subsection{Sensitivity Analysis on Climatic Adaptations}

3.5.1. Effects of Temperature Change. Temperature regime greatly influences not only the growth duration but also the growth pattern of the rice plant. During the growing season, the mean temperature, the maximum and minimum temperature, rainfall distribution pattern, and diurnal changes, or a combination of these, may be highly correlated with grain yields [27]. Effects of increase in temperature on Basmati 370 grain yield in Mwea irrigation scheme and IR 2793-80-1 rice grain yield in Ahero, West Kano, and Bunyala irrigation schemes were assessed by increasing the maximum and minimum temperatures by $+1,+2,+3,+4$, and +5 followed by subsequent simulations.

The simulated results in Table 5 show that increase in both maximum and minimum temperature led to a decrease in Basmati 370 grain yields planted under system of rice intensification in Mwea irrigation scheme. As compared to maximum temperature, increase in minimum temperature had more pronounced negative impacts on Basmati 370 yield. This more pronounced negative impact of minimum temperature on rice yield could be explained by increased respiration losses during the vegetative phase [28] and reduced grainfilling duration and endosperm cell size during the ripening phase [29].

Temperature regimes greatly influence not only the growth duration, but also the growth pattern and the productivity of rice crops. The critical temperatures for the development of the rice plant at different growth phases are highlighted by Yoshida [12] as shown in Table 6 .

Other studies on rice productivity under global warming also suggest that the productivity of rice and other tropical crops will decrease as global temperature increases. Mohandrass et al. [30], using the Hadley-coupled model, predicted a yield decrease of 14.5 percent for summer rice crops across nine experiment stations in India in 2005. Peng et al. [28] reported that the yield of dry-season rice crops in the Philippines decreased by as much as 15 percent for each $1^{\circ} \mathrm{C}$ increase in the growing season mean temperature. In Bangladesh, the impact of climate change on high yield rice varieties was studied by Karim et al.[31], using the CERES rice model and several scenarios and sensitivity analysis. They found that high temperatures reduced rice yields in all seasons in most arid locations.

At a mean maximum temperature of $27.4^{\circ} \mathrm{C}$ and a mean minimum temperature of $17.4^{\circ} \mathrm{C}$ under the SRI management practices in West Kano irrigation scheme, the model simulated the grain yield for IR 2793-80-1 under SRI to be $8.299 \mathrm{t} / \mathrm{ha}$ for West Kano environment. As shown in Table 7(a), increase in maximum temperature up to +3 led to an increase in IR 2793-80-1 grain yield and decreased beyond $+3^{\circ} \mathrm{C}$. Yield at minimum temperature also increased with increase in minimum temperature up to +2 beyond which it was not able to be simulated.

The mean maximum and minimum temperatures for the entire cropping period for Ahero irrigation scheme 2011 were $30.1^{\circ} \mathrm{C}$ and $17.0^{\circ} \mathrm{C}$, respectively. These mean temperatures resulted in a yield of $4.459 \mathrm{t} / \mathrm{ha}$. Changing these values at an interval of plus $1^{\circ} \mathrm{C}$ resulted in changes in the simulated yield as shown in Table 7(b). The simulated results in Table 7(b) show that increase in maximum temperature led to a decrease 
TABLE 4: Main growth and development variables for IR 2793-80-1 under system of rice intensification in Ahero, West Kano, and Bunyala irrigation schemes, Kenya.

\begin{tabular}{|c|c|c|c|c|c|c|}
\hline \multirow{2}{*}{ Variables } & \multicolumn{2}{|c|}{ Ahero } & \multicolumn{2}{|c|}{ West Kano } & \multicolumn{2}{|c|}{ Bunyala } \\
\hline & Simulated & Observed & Simulated & Observed & Simulated & Observed \\
\hline Anthesis & 134 & 120 & 110 & 102 & 120 & 108 \\
\hline Physiological maturity (dap) & 155 & 148 & 136 & 135 & 140 & 134 \\
\hline Yield at harvest maturity (t/ha) & 4.459 & 5.286 & 8.299 & 6.916 & 4.662 & 4.199 \\
\hline Unit grain weight at maturity (g) & 0.026 & 0.027 & 0.026 & 0.026 & 0.026 & 0.027 \\
\hline
\end{tabular}

TABLE 5: Effects of plus maximum and minimum temperatures on simulated Basmati 370 yield grain under SRI in Mwea, Kenya.

\begin{tabular}{lcc}
\hline $\begin{array}{l}\text { Plus } \\
\text { temperature } \\
\left({ }^{\circ} \mathrm{C}\right)\end{array}$ & $\begin{array}{c}\text { Grain yield at } \\
\text { maximum } \\
\text { temperature }(\mathrm{t} / \mathrm{ha})\end{array}$ & $\begin{array}{c}\text { Grain yield at } \\
\text { minimum } \\
\text { temperature }(\mathrm{t} / \mathrm{ha})\end{array}$ \\
\hline+1 & 5.413 & 5.258 \\
+2 & 5.409 & 5.128 \\
+3 & 4.355 & 4.538 \\
+4 & 4.184 & - \\
+5 & 3.69 & - \\
\hline
\end{tabular}

TABLE 6: Critical temperatures for the development of rice plant at different growth stages.

\begin{tabular}{lccc}
\hline \multirow{2}{*}{ Growth stages } & \multicolumn{3}{c}{ Critical temperature $\left({ }^{\circ} \mathrm{C}\right)$} \\
& Low & High & Optimum \\
\hline Germination & $16-19$ & 45 & $18-40$ \\
Seedling emergence & 12 & 35 & $25-30$ \\
Rooting & 16 & 35 & $25-28$ \\
Leaf elongation & $7-12$ & 45 & 31 \\
Tillering & $9-16$ & 33 & $25-31$ \\
Initiation of panicle primordial & 15 & - & - \\
Panicle differentiation & $15-20$ & 30 & - \\
Anthesis & 22 & $35-36$ & 33 \\
Ripening & $12-18$ & $>30$ & $20-29$ \\
\hline
\end{tabular}

Source: Yoshida [12].

in grain yield except for the increment of +1 and +4 . Minimum temperature increment also led to changes in yield but in a decreasing as well as increasing pattern.

Increase in maximum temperatures in Bunyala irrigation scheme led to increase in IR 2793-80-1 grain yield up to +3 beyond which it led to a decrease in yield (Table $7(\mathrm{c})$ ). Minimum temperature increase up to +1 also led to increase in yield beyond which it could not be simulated as the minimum temperature becomes unfavorable. Hardacre and TurnbulL [32] state that temperature affects the duration of crop growth and consequently the time during which incident radiation can be intercepted and transformed to dry matter. Temperature also affects final leaf number [33] and leaf canopy development $[34,35]$ which defined crop leaf area index, thereby determining the proportion of the incident radiation intercepted [36] by the crop and accumulation of dry matter. At the same time, while using ORYZA1 and INFOCROP rice simulation models at the current $\mathrm{CO}_{2}$ levels
TABLE 7: Effects of temperature change on simulated IR 2793-80-1 grain yield under SRI in West Kano, Ahero, and Bunyala irrigation schemes.

\begin{tabular}{lccc}
\hline & $\begin{array}{c}\text { Plus } \\
\text { temperature } \\
\left({ }^{\circ} \mathrm{C}\right)\end{array}$ & $\begin{array}{c}\text { Grain yield at } \\
\text { maximum } \\
\text { temperature } \\
(\mathrm{t} / \mathrm{ha})\end{array}$ & $\begin{array}{c}\text { Grain yield at } \\
\text { minimum } \\
\text { temperature } \\
(\mathrm{t} / \mathrm{ha})\end{array}$ \\
\hline (a) West & +1 & 9.036 & 8.924 \\
Kano & +2 & 9.170 & 9.170 \\
& +3 & 9.360 & - \\
& +4 & 8.689 & - \\
& +5 & 8.256 & - \\
(b) Ahero & +1 & 4.583 & 4.551 \\
& +2 & 4.496 & 4.800 \\
& +3 & 4.378 & 4.388 \\
& +4 & 4.608 & 4.874 \\
& +5 & 4.181 & 4.682 \\
\hline \multirow{3}{*}{ (c) Bunyala } & +1 & 5.631 & 4.772 \\
& +2 & 5.660 & - \\
& +3 & 6.542 & - \\
& +4 & 6.140 & - \\
\hline
\end{tabular}

of 380 ppm, Krishnan et al. [37] predicted average rice yield changes of -7.20 and $-6.66 \%$, respectively, for every $1.8^{\circ} \mathrm{C}$ increase in temperature.

Temperature is considered to be one of the dominant factors that affect the growth and yield of rice. Each phase has its low and high temperature thresholds. The effect of temperature on vegetative growth of rice plants was reviewed in relation to germination, early growth, rooting, tillering, and the critical temperature common for different physiological plant properties that were $0-3^{\circ} \mathrm{C}, 15-18^{\circ} \mathrm{C}, 30-33^{\circ} \mathrm{C}$, and $45-48^{\circ} \mathrm{C}$, respectively [38]. Low temperature in early growth stages retards the development of seedling and dry matter production [12]. In tropical regions, the temperature increase due to the climate change is probably near or above the optimum temperature range for the physiological activities of rice [39]. Such warming will thus reduce rice growth. In addition, higher temperatures will cause spikelet sterility owing to heat injury during panicle emergence [40].

Changes in mean temperatures can shorten the time to maturity of a crop, thus reducing yield. Other experimental 


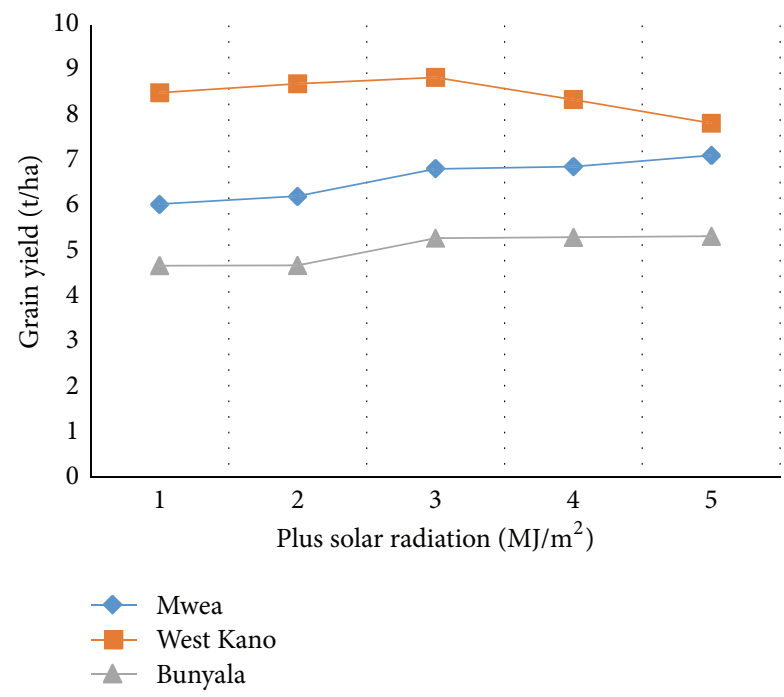

FIGURE 6: Effects of plus solar radiation on Basmati 370 grain yield in Mwea and IR 2793-80-1 grain yield in West Kano and Bunyala under SRI.

studies have also shown that even a few days of temperature above a threshold value, if coincident with anthesis, can significantly reduce yield, through affecting subsequent reproductive processes [41]. Generally, the effect of increasing temperature above the tolerance limit on rice potential production is generally negative. Temperature beyond the optimum level reduces the photosynthesis, increase the respiration and shorten the vegetation and grain-filling periods. Rice yield is negatively correlated with high $\left(>35^{\circ} \mathrm{C}\right)$ temperature during the reproductive phase [40].

3.5.2. Effects of Change in Solar Radiation. The mean solar radiation levels recorded in Mwea irrigation scheme were $16.5 \mathrm{MJ} / \mathrm{m}^{2}$ during the entire cropping period. Through sensitivity analysis, the effects of solar radiation on Basmati 370 grain yields under SRI in Mwea irrigation scheme were assessed by addition of solar radiation up to $5 \mathrm{MJ} / \mathrm{m}^{2}$ at an interval of 1 unit and their yield simulated as shown in Figure 6.

Increase in solar radiation led to an increase in grain yield for Basmati 370 cultivated under SRI in Mwea irrigation scheme. At a mean solar radiation of $16.5 \mathrm{MJ} / \mathrm{m}^{2}$, the model simulated Basmati 370 grain yield under SRI to be $5.935 \mathrm{t} / \mathrm{ha}$. Increase in solar radiation up to $5 \mathrm{MJ} / \mathrm{m}^{2} /$ day at an interval of 1 unit (Figure 6) resulted in 1.85-20\% increase in Basmati 370 grain yields under SRI. Van Keulen [42] using a simulation model predicted that an increase of $20 \%$ in total global radiation resulted in $10-20 \%$ increase in grain yield of rice. Similarly an overall decrease in solar radiation by $20 \%$ depressed the yield by $30 \%$ due to incomplete light interception during the postanthesis phase. Figure 7 shows the solar radiation requirements of rice at different stages of growth and development. Monteith [43] found the relationship between solar radiation and grain yield of wheat. The study indicated that grain yield was the product of the

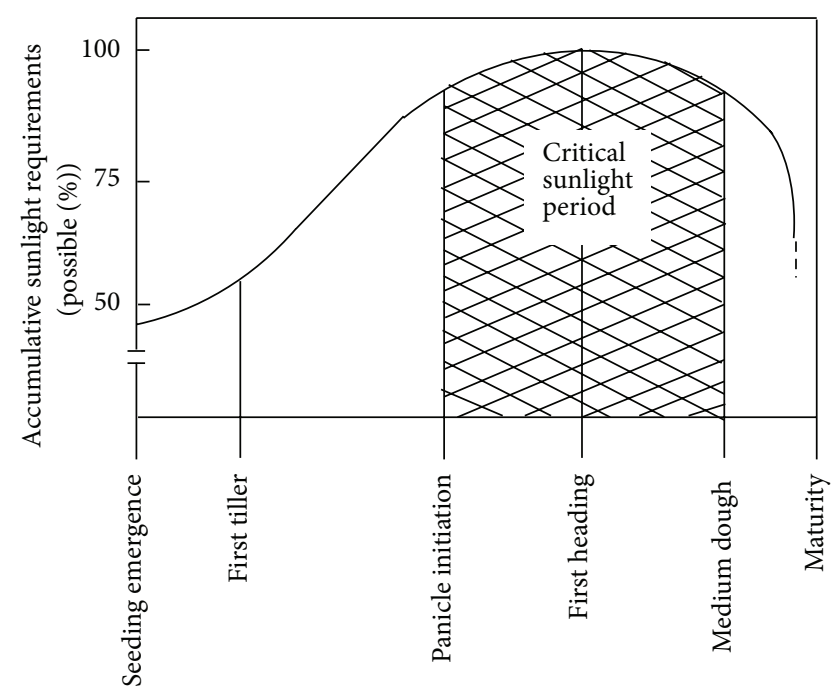

Stage of growth

FIGURE 7: Solar radiation requirements of rice at different stages of growth and development (adapted from Stansel [51]).

intercepted light, the efficiency of conversion of intercepted light to dry matter, and partitioning of dry matter to grains.

The model simulated results showed that increase in solar radiation led to an increase in grain yield for IR 2793-80-1 under SRI in West Kano irrigation scheme but up to a certain limit which in this case was $21.2 \mathrm{MJ} / \mathrm{m}^{2}$ (Figure 6). This may be attributed to the fact that vegetative growth of most plants increases linearly with solar radiation up to a limit beyond which no further increase occurs [44]. In a simulation study on the effect of solar radiation on growth of wheat and rice, it was revealed that the maximum Leaf Area Index was reduced by $7.6 \%$ in wheat and $5.9 \%$ in rice when the solar radiation was decreased by $10.0 \%$ from normal. On the other hand, with increase in radiation by $10 \%$, LAI increased in wheat by $7.1 \%$ [45]. Further, the grain yield of wheat increased from $0.7 \%$ to $6.8 \%$ and rice from $1.2 \%$ to $13 \%$ when solar radiation was increased up to $10 \%$ and the grain yield declined under decreasing amounts of solar radiation.

Increase in solar radiation in Bunyala irrigation scheme had an increasing impact on IR 2793-80-1 grain yield under SRI as shown in Figure 6. This is attributed to favourable solar radiation levels during the growth and development stages. Stansel et al. [46] state that solar radiation requirements of rice differ from one stage to another. Shading during the vegetative stages affects yield and yield components slightly. During the reproductive stages, however, shading has a very pronounced effect on spikelet number and yields. Shading during ripening periods also decreases the percentage of filled spikelets and reduces grain yields considerably.

\subsubsection{Effects of Change in Atmospheric $\mathrm{CO}_{2}$ Concentration.} The standard $\mathrm{CO}_{2}$ concentration for the current study was $380 \mathrm{ppm}$. Sensitivity analysis was done to determine the effects of change in $\mathrm{CO}_{2}$ concentration by increasing it at 


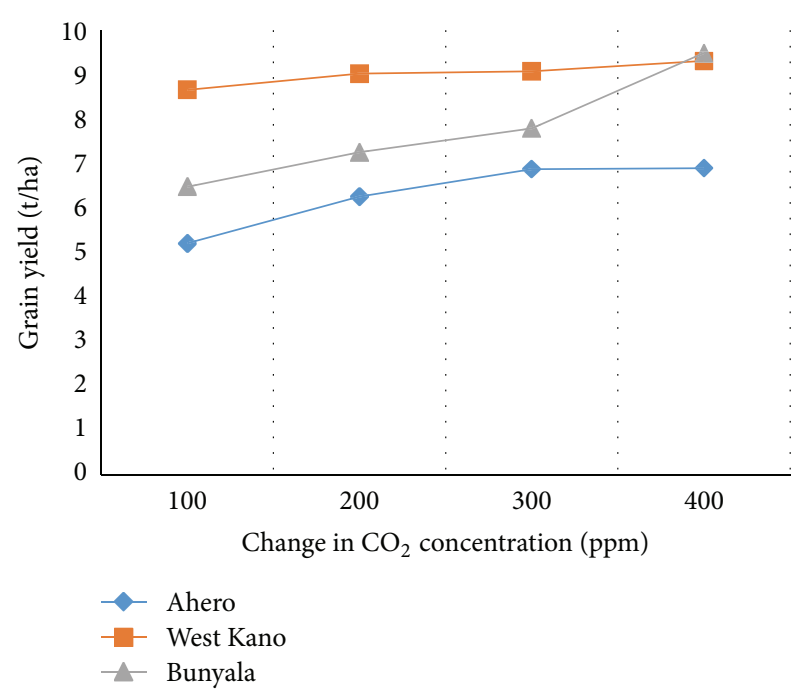

FIGURE 8: Effects of increase in $\mathrm{CO}_{2}$ concentration on IR 2793-80-1 grain yield in Ahero and West Kano irrigation schemes, Kenya.

TABLE 8: Variation in basmati 370 grain yield in Mwea irrigation scheme under SRI with increase in atmospheric $\mathrm{CO}_{2}$ concentration.

\begin{tabular}{ccccc}
\hline \multicolumn{5}{c}{ Plus $\mathrm{CO}_{2}$ concentration } \\
\hline & 100 & 200 & 300 & 400 \\
Mwea (grain yield (t/ha)) & 6.459 & 7.14 & 7.176 & 8.458 \\
\hline
\end{tabular}

an interval of $100 \mathrm{ppm}$ up to $500 \mathrm{ppm}$ from the standard concentration of $380 \mathrm{ppm}$.

Increasing the $\mathrm{CO}_{2}$ concentration by $100 \mathrm{ppm}, 200 \mathrm{ppm}$, $300 \mathrm{ppm}$, and $400 \mathrm{ppm}$ increased the Basmati 370 grain yield under SRI in Mwea irrigation scheme by $9.1 \%, 20.3 \%, 20.9 \%$, and $42.5 \%$, respectively (Table 8 ). According to Mott [47], this positive performance can be attributed to four key parameters: a decreased stomatal aperture, enhanced photosynthesis, increased total biomass, and changed biomass partitioning.

At a standard $\mathrm{CO}_{2}$ concentration of $380 \mathrm{ppm}$ in West Kano irrigation scheme, the simulated IR 2793-80-1 grain yield under SRI was $8.299 \mathrm{t} / \mathrm{ha}$. Increase in $\mathrm{CO}_{2}$ concentration in West Kano irrigation scheme led to an increase in IR 2793-80-1 grain yield under SRI. Compared to the yield at standard $\mathrm{CO}_{2}$ concentration, increase in $\mathrm{CO}_{2}$ concentration by $100 \mathrm{ppm}, 200 \mathrm{ppm}, 300 \mathrm{ppm}$, and $400 \mathrm{ppm}$ led to a $4.3 \%$, $8.7 \%, 9.4 \%$, and $12.2 \%$ increase in IR $2793-80-1$ grain yield, respectively, under SRI (Figure 8).

Carbon dioxide is the prime substrate for photosynthesis. Majority of plants, including rice, fixed $\mathrm{CO}_{2}$ via $\mathrm{C} 3$ pathway. At ambient $\mathrm{CO}_{2}$ levels, $\mathrm{C} 3$ pathway is less efficient than $\mathrm{C} 4$ pathway due to the enzyme. Rubisco has dual and competing affinity to both $\mathrm{O}_{2}$ and $\mathrm{CO}_{2}$. At elevated $\mathrm{CO}_{2}$, the carboxylation rate increases which will increase photosynthesis of $\mathrm{C} 3$ plants. Studies with rice have indicated that elevated $\mathrm{CO}_{2}$ generally increases tiller number, photosynthesis, biomass, and grain yield as well as plant nitrogen $(\mathrm{N})$ uptake and biological $\mathrm{N}$ fixation [48].
Simulations of IR 2793-80-1 grain yield under different concentrations $\mathrm{CO}_{2}$ in Ahero irrigation scheme are shown in Figure 8. These predictions were made using a standard concentration of atmospheric $\mathrm{CO}_{2}$ of $380 \mathrm{ppm}$ and then increased at a level of $100 \mathrm{ppm}, 200 \mathrm{ppm}, 300 \mathrm{ppm}$, and $400 \mathrm{ppm}$. Increasing the $\mathrm{CO}_{2}$ concentration by $100 \mathrm{ppm}$ and $400 \mathrm{ppm}$ from the standard $\mathrm{CO}_{2}$ concentration of $380 \mathrm{ppm}$ led to $16.8 \%$ and $54.2 \%$ increase in grain yield, respectively.

At $380 \mathrm{ppm}$ standard $\mathrm{CO}_{2}$ concentration in Bunyala irrigation scheme during 2011, the model simulated a yield of $4.662 \mathrm{t} / \mathrm{ha}$ for IR 2793-80-1 under SRI. Increasing the concentration by $100 \mathrm{ppm}, 200 \mathrm{ppm}, 300 \mathrm{ppm}$, and $400 \mathrm{ppm}$ from the standard concentration, the effects of change in $\mathrm{CO}_{2}$ on IR 2793-80-1 under SRI were assessed and the corresponding yields were simulated as shown in Table 8 . The results in Table 8 reveal that increase in $\mathrm{CO}_{2}$ concentration in Bunyala irrigation scheme led to an increase in IR2793-80-1 grain yield cultivated under SRI. Increasing the $\mathrm{CO}_{2}$ concentration by $100 \mathrm{ppm}$ led to $39.0 \%$ increase in grain yield, $200 \mathrm{ppm}$ by $55.6 \%$, and $300 \mathrm{ppm}$ by $67.1 \%$ and $400 \mathrm{ppm}$ by $81.9 \%$. Similar studies indicate that rice is particularly responsive to increased carbon dioxide concentration. According to Hunsaker et al. [49], high carbon dioxide concentrations increase water use efficiency. In addition, high carbon dioxide levels increase plants' resistance to salinity and drought and increase nutrient uptake [50].

\section{Conclusion}

Weather changes affect Basmati 370 and IR 2793-80-1 yield under SRI in Kenya. Increase in maximum and minimum temperatures beyond optimum temperatures for rice production led to a decrease in yield and minimum temperature changes had more profound negative impacts as compared to maximum temperature changes. Change in atmospheric $\mathrm{CO}_{2}$ concentration led to an increase in Basmati 370 and IR 2793-80-1 grain yield. Increase in solar radiation in Mwea irrigation scheme led to an increase in Basmati 370 grain yield and also an increase in IR 2793-80-1 grain yield in West Kano and Bunyala irrigation schemes. Therefore to improve rice production under system of rice intensification in Kenya, proper understanding of the prevailing weather conditions and regular monitoring is necessary.

\section{Conflict of Interests}

The authors declare that they have no conflict of interests regarding the publication of this paper.

\section{Acknowledgments}

The authors are grateful to the National Irrigation Board (NIB) for their financial support towards this project under the SRI/NIB upscaling project. Special thanks go to Professor Gerrit of Washington University, USA, for his comprehensive support towards acquisition of the DSSAT software and his enviable advice during model simulation. MIAD and JKUAT laboratories are acknowledged for their assistance on soil 
and plant analysis, and the authors also acknowledge all the staff and farmers in Mwea, Ahero, West Kano, and Bunyala irrigation schemes for their support during data collection.

\section{References}

[1] J. K. Basak, M. A. Ali, N. M. Islam, and A. M. Rashid, "Assessment of the climate change on boro rice production in Bangladesh using DSSAT model," Journal of Civil Engineering (IEB), vol. 38, no. 2, pp. 95-108, 2010.

[2] S. M. King'uyu, L. A. Ogallo, and E. K. Anyamba, "Recent trends of minimum and maximum surface temperatures over Eastern Africa," Journal of Climate, vol. 13, no. 16, pp. 2876-2885, 2000.

[3] GoK, National Climate Change Response Strategy: Executive Brief, Ministry of Environment and Mineral Resources, Government of Kenya (GoK), Nairobi, Kenya, 2010.

[4] SEI, The Economics of Climate Change in Kenya, Stockholm Environment Institute, Oxford, UK, 2009.

[5] M. K. Kilavi, "Analyzing the temporal characteristics of extreme temperature events over ASALs and the coastal regions of Kenya as an indicator of climate change," 2008.

[6] D. Berkelaar, "SRI, the system of rice intensification: less can be more," ECHO Development Notes, vol. 10, no. 70, pp. 1-7, 2001.

[7] N. Uphoff and A. Kassam, "Case study: system of rice intensification, in agricultural technologies for developing countries," Final Report, Annex 3, European Technology Assessment Group, Karlsruhe, Germany, 2009.

[8] A. S. Nain and K. C. Kersebaum, "Calibration and validation of CERES model for simulating water and nutrients in Germany," in Modelling Water and Nutrient Dynamics in Soil-Crop Systems, chapter 12, pp. 161-181, Springer, Amsterdam, The Netherlands, 2007.

[9] H. Pathak, C. Li, and R. Wassmann, "Greenhouse gas emissions from Indian rice fields: calibration and upscaling using the DNDC model," Biogeosciences Discussions, vol. 2, no. 1, pp. 77102, 2005.

[10] V. D'Costa, Characterization and interpretation of the soils of the Kano plains for irrigation agriculture [M.S. thesis], University of Nairobi, 1973.

[11] R. Niemeijer and J. Hoorweg, "Commercialization of rice and nutrition: a case from West Kenya," in Agricultural Commercialization, Economic Development and Nutrition, J. von Brann and E. Kennedy, Eds., p. 267, The Johns Hopkins University Press, Baltimore, Md, USA, 1994, http://www.ifpri.org/sites/default/files/pubs/pubs/books/ vonbraun94/vonbraun94ch17.pdf.

[12] S. Yoshida, “Tropical climate and its influence on rice," IRRI Research Paper Series 20, IRRI, Los Baños, Philippines, 1978.

[13] N. Uphoff, "higher yields with fewer external inputs? The system of rice intensification and potential contributions to agricultural sustainability," International Journal of Agricultural Sustainability, vol. 1, no. 1, pp. 38-50, 2003.

[14] IBSNAT, The IBNET Decade, Department of Agronomy and Soil Science, College of Tropical Agriculture and Human Resources, University of Hawaii, Honolulu, Hawaii, USA, 1993.

[15] J. T. Ritchie, E. C. Alocilja, U. Singh, and G. Uehara, "IBSNAT and the CERES-rice model," in Weather and Rice: Proceedings of the International Workshop on the Impact of Weather Parameters on Growth and Yield of Rice, 7-10 April 1986, pp. 271-281, International Rice Research Institute, Manila, Philippines, 1987.
[16] J. A. Ndiiri, B. M. Mati, P. G. Home, B. J. Odongo, and N. Uphoff, "Comparison of water saving of paddy rice under system of rice Intensification (SRI) growing in Mwea, Kenya," International Journal of Current Research and Review, vol. 4, no. 6, 2012.

[17] L. Ma and H. M. Selim, "Predicting atrazine adsorptiondesorption in soils: a modified second-order kinetic model," Water Resources Research, vol. 30, no. 2, pp. 447-456, 1994.

[18] L. R. Ahuja, L. Ma, and T. A. Howell, Agricultural System Models in Field Research and Technology Transfer, CRC Press, New York, NY, USA, 2002.

[19] K. Loague and R. E. Green, "Statistical and graphical methods for evaluating solute transport models: overview and application," Journal of Contaminant Hydrology, vol. 7, no. 1-2, pp. 5173, 1991.

[20] R. K. Hay and A. J. Walker, An Introduction to the Physiology of Crop Yield, Longman Scientific and Technical, Harlow Essex, UK, 1989.

[21] U. Sing, D. C. Godwin, J. T. Ritchie et al., "Ceres-Rice 3.5 (98.0)," International Fertilizer Development Research Center. (Ricer980.EXE Program file), 1998.

[22] L. A. Hunt, J. T. Ritchie, P. S. Teng, and K. J. Boote, "Genetic Coefficients for the IBSNAT crop models," in Agronomy Abstract, pp. 16-17, ASA, Madison, Wis, USA, 1989.

[23] B. Acock and M. C. Acock, "Potential for using long-term field research data to develop and validate crop simulation," Agronomy Journal, vol. 83, no. 1, pp. 56-61, 1991.

[24] L. A. Hunt and S. Pararajaingham, "GENCALC: genotype coefficient calculator," in Users Guide Version 3.0, Publication No. LAH-01-94, Crop Simulation Series No. 3, Department of Crop science, University of Guelph, 1994.

[25] C. J. Willmott, "Some comments on the evaluation of model performance," Bulletin of the American Meteorological Society, vol. 63, no. 11, pp. 1309-1313, 1982.

[26] A. S. Toit and D. L. Toit, "Short description of the model statistical package and weather analogue program," Report, University of Florida, Gainesville, Fla, USA, 2003.

[27] J. C. Moomaw and B. S. Vergara, "The environment of tropical rice production," 1965.

[28] S. Peng, J. Huang, J. E. Sheehy et al., "Rice yield decline with higher night temperature from global warming," in Rice Integrated Crop Management: Towards a Ricecheck System in the Philippines, E. D. Redona, A. P. Castro, and G. P. Llanto, Eds., pp. 46-56, PhilRice, Nueva Ecija, Philippines, 2004.

[29] S. Morita, J. Yonemaru, and J. Takanashi, "Grain growth and endosperm cell size under high night temperatures in rice (Oryza sativa L.)," Annals of Botany, vol. 95, no. 4, pp. 695-701, 2005.

[30] S. Mohandrass, A. A. Kareem, T. B. Ranganathan, and S. Jeyaraman, "Rice production in India under the current and future climate," in Modeling the Impact of Climate: Change on Rice Production in Asia, B. Mathews, M. J. Kroff, D. Bachelet, and H. H. van Laar, Eds., pp. 165-181, CABI, Wallingford, UK, 1995.

[31] Z. Karim, M. Ahmed, S. G. Hussain, and K. B. Rashid, "Impact of climate change on the production of modern rice in Bangladesh," in Implications of Climate Change for International Agriculture: Crop Modeling Study, C. Rosenzweig and A. Iglesias, Eds., EPA 230-B-94-003, US Environmental Protection Agency, Washington, DC, USA, 1994.

[32] A. K. Hardacre and H. I. TurnbulL, "The growth and development of maize (Zea mays L.) at five temperatures," Annuals of Botany, vol. 58, pp. 779-787, 1986. 
[33] J. C. Stevenson and M. M. Goodman, "Ecology of exotic races of maize: 1. Leaf number and tillering of 16 races under four temperatures and two photoperiods," Crop Science, vol. 12, no. 6, pp. 864-868, 1972.

[34] M. Tollenaar, T. B. Daynard, and R. B. Hunter, "Effect of temperature on rate of leaf appearance and flowering date in maize," Crop Science, vol. 19, no. 3, pp. 363-366, 1979.

[35] M. R. Thiagarajah and L. A. Hunt, "Effects of temperature on leaf growth in corn (Zea mays L.)," Cannadian Journal of Botany, vol. 60 , no. 9, pp. 1647-1652, 1982.

[36] R. C. Muchow and P. S. Carberry, "Designing improved plant types for the semiarid tropics: agronomists view points," in Systems Approaches for Agricultural Development, F. W. T. P. de Vries, Ed., pp. 37-61, Kluwer Academic Press, Dordrecht, The Netherlands, 1993.

[37] P. Krishnan, D. K. Swain, B. C. Bhaskar, S. K. Nayak, and R. N. Dash, "Impact of elevated $\mathrm{CO}_{2}$ and temperature on rice yield and methods of adaptation as evaluated by crop simulation studies," Agriculture, Ecosystems and Environment, vol. 122, no. 2, pp. 233-242, 2007.

[38] I. Nishiyama, Climate and Rice, IRRl, 1976.

[39] K. P. Hogan, A. P. Smith, and L. H. Ziska, "Potential effects of elevated $\mathrm{CO}_{2}$ and changes in temperature on tropical plants," Plant, Cell and Environment, vol. 14, no. 8, pp. 763-778, 1991.

[40] T. Satake and S. Yoshida, "High temperature-induced sterility in indica rice at flowering," Japanese Journal of Crop Science, vol. 47, no. 1, pp. 6-17, 1978 (Japanese).

[41] T. R. Wheeler, P. Q. Craufurd, R. H. Ellis, J. R. Porter, and P. V. V. Prasad, "Temperature variability and the yield of annual crops," Agriculture, Ecosystems and Environment, vol. 82, no. 1-3, pp. 159-167, 2000.

[42] H. Van Keulen, "Potential wheat yields in Zambia-a simulation approach," Agricultural Systems, vol. 14, no. 3, pp. 171-192, 1984.

[43] J. L. Monteith, "Solar radiation and productivity in tropical ecosystems," Journal of Applied Ecology, vol. 9, no. 3, pp. 747766, 1972.

[44] http://www.fao.org/docrep/x5648e/x5648e0e.htm.

[45] S. S. Hundal and P. Kaur, "Environment and the effect of environmental stresses on potential production of major cereal crops in Punjab," in Proceedings of the International Conference on Sustainable Agriculture, pp. 11-12, Haryana Agricultural University, Hisar, India, January 1995.

[46] J. Stansel, C. N. Bollich, J. R. Thysell, and V. L. Hall, "The influence of light intensity and nitrogen fertility on rice yields and components of rice," Rice Journal, vol. 68, no. 4, pp. 34-35, 1965.

[47] K. A. Mott, "Do stomata respond to $\mathrm{CO}_{2}$ concentrations other than intercellular?" Plant Physiology, vol. 86, no. 1, pp. 200-203, 1988.

[48] W. G. Cheng, K. Inubushi, K. Yagi, H. Sakai, and K. Kobayashi, "Effects of elevated carbon dioxide concentration on biological nitrogen fixation, nitrogen mineralization and carbon decomposition in submerged rice soil," Biology and Fertility of Soils, vol. 34, no. 1, pp. 7-13, 2001.

[49] D. J. Hunsaker, B. A. Kimball, P. J. Pinter Jr. et al., " $\mathrm{CO}_{2}$ enrichment and soil nitrogen effects on wheat evapotranspiration and water use efficiency," Agricultural and Forest Meteorology, vol. 104, no. 2, pp. 85-105, 2000.

[50] C. Kaya, H. Kirnak, and D. Higgs, "Effects of supplementary potassium and phosphorus on physiological development and mineral nutrition of cucumber and pepper cultivars grown at high salinity ( $\mathrm{NaCl})$," Journal of Plant Nutrition, vol. 24, no. 9, pp. 1457-1471, 2001.

[51] J. W. Stansel, "Effective utilization of sunlight," in Six Decades of Rice Research in Texas, vol. 4 of Research Monograph, pp. 4350, Texas Agricultural Experiment Station, U.S. Department of Agriculture, 1975. 


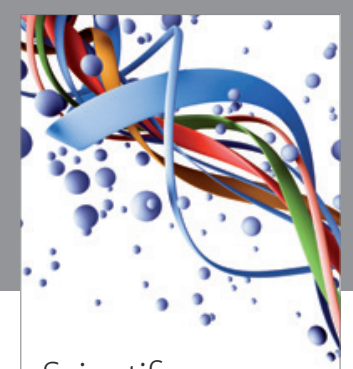

Scientifica
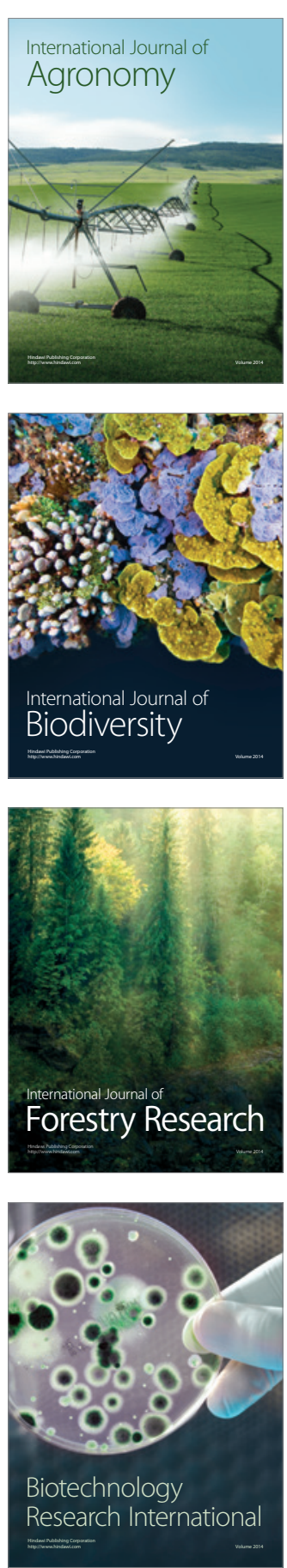
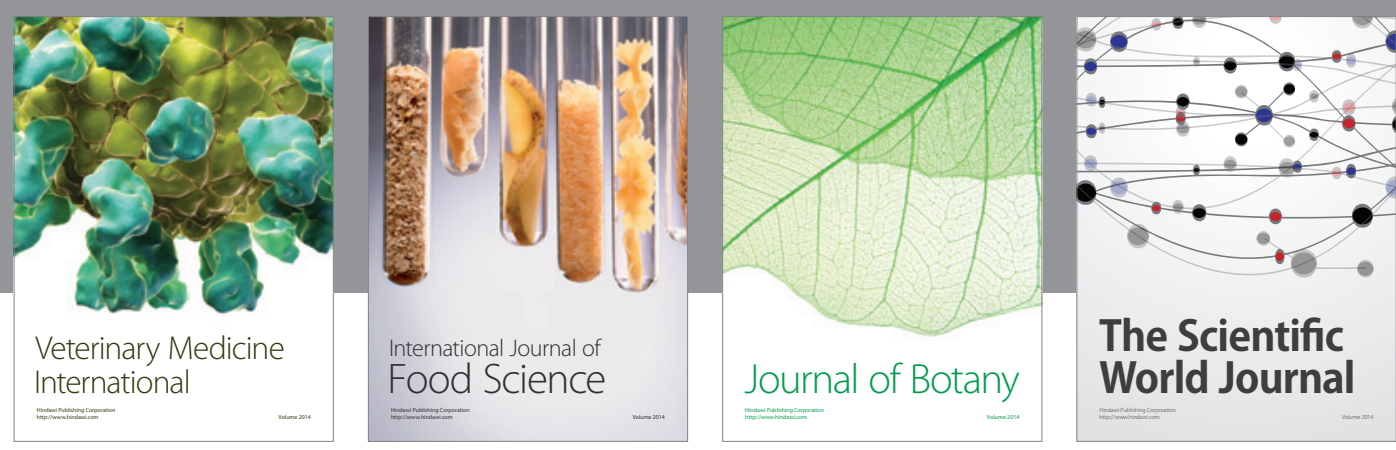

The Scientific World Journal
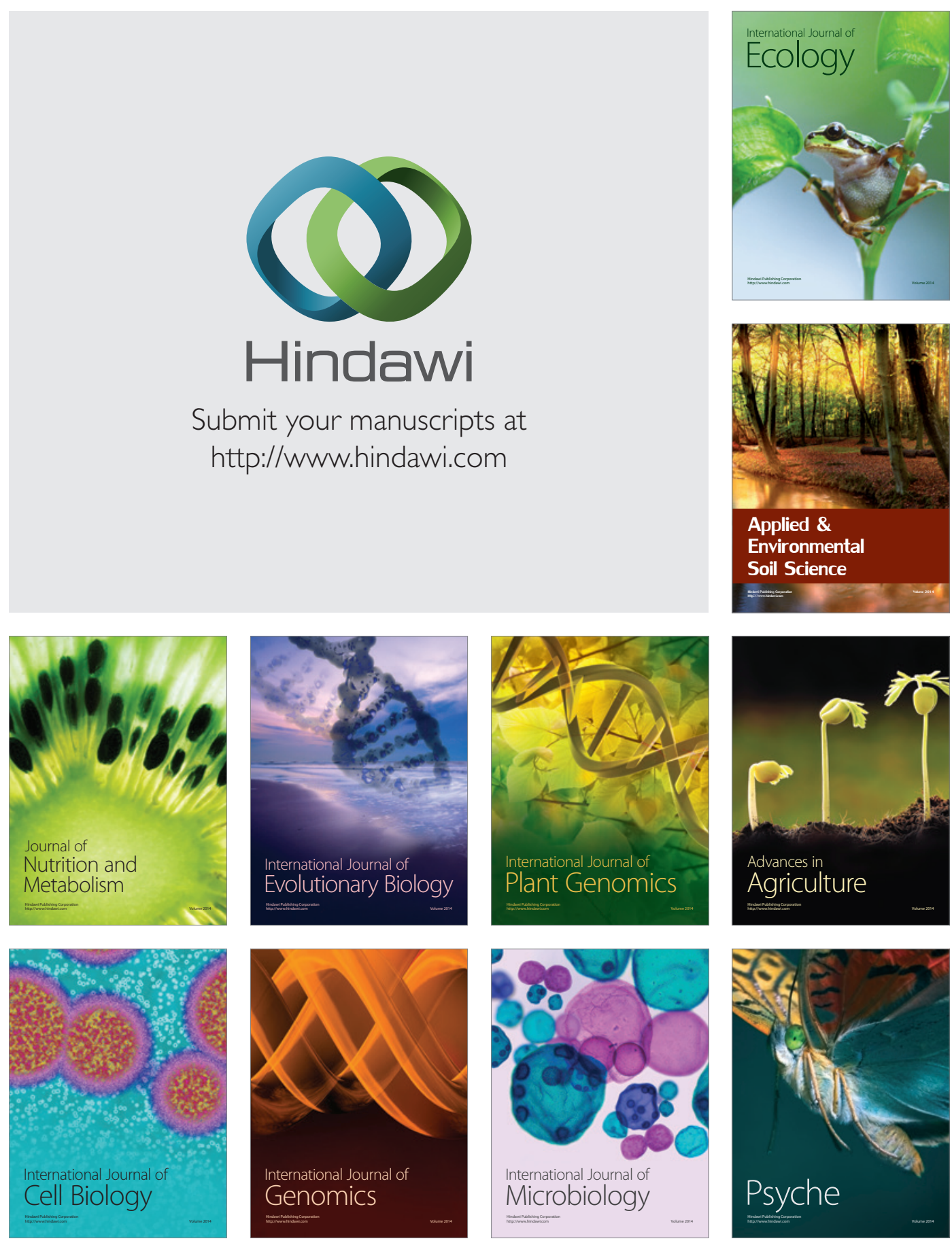